\title{
STUDI KEBIJAKAN PERLINDUNGAN KESEHATAN REPRODUKSI \\ BAGI PEKERJA PEREMPUAN \\ [Analisa Terhadap Undang-Undang Ketenagakerjaan No. 13 tahun 2003]
}

\author{
Margaret Aliyatul Maimunah*) dan Begum Fauziyah**) \\ *) Tenaga Ahli Komisi VIII DPR RI \\ **) Dosen Fakultas Sains dan Teknologi UIN Maulana Malik Ibrahim
}

\begin{abstract}
The development of industries in the development countries nowadays has caused the availability of many chances for woman to be employee, sch as in electronical industry, textile and foodstuff manufacture. In the fact, the increasement of woman employees in the industrial company does not be followed by the guarantee of woman rights especially in getting healthy reproduction protection. This paper consist of the analysis of the right of woman employee in getting healthy reproduction protection, especially in UU No. 3/2003 about employment. In this paper, the analyst analyze the paragraphs telling about the rights of healthy reproduction in UU No. 3/2003. They are, what are the rights of healthy reproduction in woman employee told in UU No. 3/2003; how is the formulation of paragraphs in UU No.3/2003 describes the healthy reproduction in woman employee and how is the implementation of UU No. 3/2003 based on the previous studies?.

The result of this analysis is UU No. 3/2003 telling about employee has arranged the rights of woman employee in getting healthy reproduction. They are, the rights of leave because of menstruation on the first and second day; the rights of leave because of give birth on 1.5 months before and after. The rights of time because of suckle and the rights of leave because of miscarriage. However, these paragraphs not totally give protection yet. Beside, the existence of those paragraphs still have many weaknesses that perhaps let the capitalist take the benefit by using money as a power and authority to control woman employee. So that, it needs revition of UU No. 3/2003 about employment. They are recovered the right of woman employee in getting healthy reproduction and closed the capitalist to take benefit.
\end{abstract}

\section{PENDAHULUAN}

Pada dekade 1960-an, proses dan paradigma pembangunan Indonesia dilakukan dengan mengacu pada teori pembangunan yang dicetuskan oleh Rostow (Fakih, 1997). Proses dan paradigma pembangunan berdasarkan teori Rostow dilakukan untuk mengubah nilai-nilai tradisional yang identik dengan pertanian menuju kemajuan teknologi yang identik dengan perkembangan industri. Industrialisasi di negara-negara dunia ketiga telah menyebabkan pasaran tenaga kerja untuk perempuan semakin terbuka. Tenaga kerja perempuan, utamanya perempuan muda, kini mulai banyak dilibatkan di industri padat karya seperti di pabrik tekstil, elektronik dan pengolahan bahan makanan (Saptari dan Holzner, 1997). 
Peningkatan jumlah pekerja pada sektor industri dapat dilihat berdasarkan data dari BPS tahun 2010. Pada bulan Februari tahun 2010, jumlah angkatan kerja mencapai 116 juta orang. Jumlah tersebut naik sebanyak 2,92 juta orang dibandingkan jumlah angkatan kerja pada bulan Februari tahun 2009. Kenaikan jumlah angkatan kerja pada bulan februari 2010 tidak diikuti kenaikan jumlah pekerja dari seluruh sector melainkan hanya pada beberapa sector. Sektor-sektor yang mengalami penurunan jumlah pekerja terbesar adalah sektor pertanian sebesar 200 ribu orang $(0,47 \%)$ dan sektor transportasi sebesar 130 ribu orang $(2,19 \%)$. Sementara, sektor jasa kemasyarakatan, industri dan perdagangan menjadi penyumbang terbesar penyerapan tenaga kerja pada bulan Februari 2010.

Secara umum, dilihat pada kondisi tahun 2006, 2007 dan 2008, tingkat partisipasi angkatan kerja perempuan jauh lebih rendah dibandingkan laki-laki. Meskipun demikian, selama periode 2006-2008 telah terjadi peningkatan jumlah angkatan kerja perempuan yang jauh lebih besar dibandingkan dengan peningkatan jumlah angkatan kerja laki-laki. Jumlah angkatan kerja perempuan pada tahun 2006 mencapai 38,6 juta orang dan meningkat hingga 42,8 juta orang pada tahun 2008, sementara angkatan kerja laki-laki meningkat dari 67,7 juta orang menjadi 69,1 juta orang dalam waktu yang sama (SAKERNAS, 2006, 2007, 2008).

Permasalahan yang kemudian muncul adalah semakin meningkatnya jumlah pekerja perempuan dalam dunia industri, tidak disertai dengan adanya jaminan akan hak-hak pekerja perempuan. Secara lebih spesifik, pekerja perempuan sering mengalami masalah diskriminasi seperti mendapatkan upah lebih rendah dibandingkan laki-laki. Kondisi ini disebabkan oleh adanya pandangan bahwa partisipasi perempuan dalam dunia kerja adalah untuk menambah penghasilan keluarga atau membantu suami dalam mencari nafkah untuk keluarganya. Selain itu, perempuan cenderung ditempatkan pada posisi kerja yang dianggap dekat dengan karakter yang dianggap lekat dengan perempuan, seperti sabar, telaten, rapi, dan lain sebagainya dan sebaliknya perempuan pun menjadi sulit untuk menempati posisi yang dianggap lebih sesuai dengan karakter yang dianggap dekat dengan karakter laki-laki, yaitu tegas, berani, dan lain sebagainya.

Selain praktik-praktik diskriminasi tersebut, menurut Syafa'at (1998), pekerja perempuan diidentifikasi mengalami lima bentuk kekerasan. Salah satunya adalah kekerasan terhadap reproduksi biologisnya. Dalam dunia industri, pekerja perempuan seringkali merasa kesulitan untuk mendapatkan hak dan perlindungan terhadap kesehatan reproduksinya, seperti cuti keguguran, cuti melahirkan, dan lain sebagainya. Untuk mendapatkan perlindungan terhadap kesehatan reproduksinya, pekerja perempuan seringkali harus berhadapan dengan relasi industri yang lebih memikirkan nilai ekonomi. Sebagai contoh, kekerasan yang terjadi 
ketika pekerja perempuan terpaksa bekerja meskipun sedang haid karena prosedur cuti yang sulit dan adanya sistem pengupahan perusahaan.

Perlindungan mengenai kesehatan reproduki bagi pekerja perempuan sebenarnya telah diatur dalam Undang-Undang no.13 tahun 2003 tentang Ketenagakerjaan. Namun, dalam realitanya, masih banyak pekerja perempuan yang belum mendapatkan perlindungan terhadap kesehatan reproduksinya sebagaimana yang telah termaktub dalam Undang-Undang tersebut. Berdasarkan kondisi di atas, penulis tertarik untuk menganalisa secara langsung pasal Undang-Undang No. 13 tahun 2003 tentang Ketenagakerjaan, khususnya yang berkaitan dengan kebijakan perlindungan kesehatan reproduksi.

Fischer yang mengadopsi pemikiran dari Jurgen Habermas (1972) menyatakan "policy advisor were not neutral" (Bacchi, 1999). Pendapat ini memberikan pemahaman, bahwa setiap keputusan yang dilahirkan tidak akan pernah terbebas dari segala yang melingkupi para pembuatnya. Pendapat tersebut senada dengan yang disampaikan Friedman (1975) bahwa pengkajian terhadap hukum tidak bisa dilakukan hanya pada kajian terhadap produk hukum secara tekstual an sich. Akan tetapi, kajian terhadap hukum harus dilakukan dengan melihat hukum sebagai suatu sistem yang terdiri dari tiga komponen yang terkait dan saling mempengaruhi satu sama lain dalam pelaksanaannya, yaitu substansi hukum (aturan-aturan dan norma-norma), struktur hukum (institusi/para penegak hukum seperti polisi, jaksa, dan hakim), dan budaya hukum (ide-ide, sikap-sikap, kepercayaan, harapan, dan pandangan tentang hukum).

Sejalan dengan pendapat di atas adalah teori tentang relasi antara kehidupan dan hukum yang dicetuskan oleh MacKinnon (1989). Ia mengatakan bahwa pengalaman kehidupan manusia didasarkan oleh relasi antara laki-laki dan perempuan. Oleh karena itu, jika kehidupan diadopsi untuk menjadi sebuah hukum, maka transformasi akan terjadi baik secara formal maupun substantif.

Berdasarkan berbagai pemikiran dan realitas di atas, maka analisa terhadap UndangUndang no. 13 tahun 2003 tentang ketenagekerjaan ini dilakukan dengan menggunakan pendekatan hukum yang berperspektif perempuan. Menurut Cossman sebagaimana dikutip oleh Irianto (2000), pendekatan hukum berperspektif perempuan meliputi beberapa hal, yaitu: a) menguji apakah hukum gagal memperhitungkan pengalaman perempuan atau adanya standar ganda dan konsep hukum telah merugikan perempuan; b) mempertanyakan implikasi gender dari hukum yang mengabaikan perempuan dengan melihat ada apa dibalik rumusanrumusan hukum yang ada; c) menggunakan kasus-kasus pengalaman perempuan sebagai unit analisis untuk melihat hubungan kekuasaan antara laki-laki dan perempuan. 
Oleh karena itu, analisa terhadap pasal-pasal yang mengatur hak-hak kesehatan reproduksi dalam Undang-Undang no. 13 tahun 2003 tentang ketenagekerjaan ini dimaksudkan untuk melihat :

1. Apa saja hak-hak kesehatan reproduksi pekerja perempuan yang diatur dalam UndangUndang no. 13 tahun 2003 ?

2. Bagaimana rumusan pasal-pasal dalam Undang-Undang no. 13 tahun 2003 tentang Ketenagakerjaan menggambarkan hak-hak kesehatan reproduksi pekerja perempuan serta menempatkan pekerja perempuan dan mengakomodir pekerja perempuan terkait dengan kesehatan reproduksinya.

3. Bagaimana rumusan pasal-pasal dalam Undang-Undang no. 13 tahun 2003 yang mengatur tentang hak-hak kesehatan reproduksi pekerja perempuan diimplementasikan?.

\section{Kebijakan Perlindungan Kesehatan Reproduksi bagi Perempuan}

Kesehatan reproduksi adalah keadaan sejahtera secara fisik, mental, dan sosial yang bukan karena ketiadaan penyakit dan kecacatan yang berkaitan dengan sistem, fungsi, dan proses-prosesnya. (WHO, 1992). Berdasarkan definisi tersebut, maka perempuan seharusnya mendapatkan perlindungan kesehatan sesuai dengan tahap siklus kehidupannya (life cycle), meliputi: 1) perkembangan seksual sejak lahir, masa anak-anak dan remaja; 2) kehamilan remaja dan kehamilan yang tidak dikehendaki; 3) aborsi; 4) komplikasi kehamilan, persalinan dan nifas; 5) penggunaan kontrasepsi; 6) pemberian ASI; 7) infeksi saluran reproduksi termasuk HIV/AIDS; 8) infertilitas; 9) pre dan pasca menopause; 10) kanker organ reproduksi dan ; 11) gaya hidup seseorang, termasuk perilaku seksual yang menyimpang. Dalam perspektif Hak Asasi Manusia (HAM), kesehatan reproduksi terkait erat dengan peran perempuan dalam mengambil keputusan secara mandiri tentang fungsi reproduksinya, khususnya bagi perempuan yang berada dalam usia reproduksi, yaitu 15-45 tahun (Sadli dkk., 2006).

Hak-Hak kesehatan reproduksi perempuan telah diatur dalam berbagai kebijakan. Pertama adalah dalam konvensi penghapusan segala bentuk diskriminasi terhadap wanita atau yang biasa dikenal dengan CEDAW, disahkan dan dinyatakan berlaku pada tahun 1981 setelah disetujui oleh 20 negara. Indonesia meratifikasi CEDAW dan dituangkan dalam UU no.7 tahun 1984 tentang pengesahan mengenai konvensi penghapusan segala bentuk diskriminasi terhadap wanita. Hak kesehatan reproduksi perempuan yang diatur dalam konvensi ini terdapat pada pasal 12 tentang kesehatan dan Keluarga Berencana (Luhulima dkk., 2000). 
Selain itu, hak-hak kesehatan reproduksi juga diatur dalam Konferensi Internasional tentang kependudukan dan pembangunan (International Conference on Population and Development-ICPD) di Kairo. Hak-hak kesehatan reproduksi perempuan yang diatur dalam ICPD ini meliputi: 1) pelayanan semaa kehamilan, melahirkan, dan pasca melahirkan; 2) pelayanan kemandulan; 3) pelayanan KB yang optimal; 4) pelayanan dan penyuluhan penyakir menular seksual dan HIV/AIDS; 5) pelayanan aborsi; 6) pelayanan dan pemberian komunikasi, informasi, dan edukasi (KIE) yang berkaitandengan kesehatan reproduksi; 7) pelayanan kesehatan seksual dan reproduksi remaja; 8) partisipasi laki-laki dan tanggungjawab keluarga; 9) peniadaan sunat dan mutilasi anak perempuan; 10) pelayanan kesehatan lansia (Sadli dkk., 2006).

Kebijakan tersebut diperkuat dalam Millenium Development Goals (MDGS). Salah satu tujuan MDGS adalah menurunkan angka kematian anak, meningkatkan kesehatan ibu dan menurunkan angka kematian ibu, dan memerangi HIV/AIDS Malaria, dan penyakit menular lainnya. (Sadli dkk., 2006).

Kebijakan Perlindungan Kesehatan Reproduksi Perempuan dalam Undang-Undang No. 13 tahun 2003 tentang Ketenagakerjaan

Undang-Undang no. 13 tahun 2003 tentang ketenagakerjaan telah mengatur perlindungan mengenai kesehatan reproduksi bagi pekerja perempuan yang termaktub dalam pasal 76 ayat 2, pasal 81 ayat 1, Pasal 82 ayat 1 dan ayat 2, Pasal 83, Pasal 84, pasal 93 ayat 2 dan ayat 4, Pasal 153 ayat 1, pasal 185 ayat 1, Pasal 186 ayat 1, dan pasal 187 ayat 1 . Bentukbentuk perlindungan terhadap kesehatan reproduksi bagi pekerja perempuan yang diatur dalam Undang-undang ini adalah sebagai berikut:

Tabel 1. Aturan-Aturan tentang Perlindungan Kesehatan Reproduksi bagi Pekerja Perempuan dalam Undang-Undang No. 13 tahun 2003 tentang Ketenagakerjaan

\begin{tabular}{|l|c|c|c|}
\hline No & Pasal & Bentuk-Bentuk Perlindungan Kesehatan Reproduksi bagi \\
\hline
\end{tabular}




\begin{tabular}{|c|c|c|}
\hline & & $\begin{array}{l}\text { Pekerja Perempuan } \\
\end{array}$ \\
\hline 1. & Pasal 76 & $\begin{array}{l}\text { (2) Pengusaha dilarang mempekerjakan pekerja/buruh perempuan } \\
\text { hamil yang menurut dokter berbahaya bagi kesehatan dan } \\
\text { keselamatan kandungannya maupun dirinya apabila bekerja } \\
\text { antara pukul } 23.00 \text { s.d. } 07.00\end{array}$ \\
\hline 2. & Pasal 81 & $\begin{array}{l}\text { (1) Pekerja/buruh perempuan yang dalam masa haid merasakan } \\
\text { sakit dan memberitahukan kepada pengusaha, tidak wajib } \\
\text { bekerja pada hari pertama dan kedua pada waktu haid. }\end{array}$ \\
\hline 3. & Pasal 82 & $\begin{array}{l}\text { (1) Pekerja/buruh perempuan berhak memperoleh istirahat selama } \\
1,5 \text { (satu setengah) bulan sebelum saatnya melahirkan anak dan } \\
1,5 \text { (satu setengah) bulan sesudah melahirkan menurut } \\
\text { perhitungan dokter atau bidan } \\
\text { (2) Pekerja/buruh perempuan yang mengalami keguguran } \\
\text { kandungan berhak memperoleh istirahat 1,5 (satu setengah) } \\
\text { bulan atau sesuai dengan surat keterangan dokter kandungan } \\
\text { atau bidan. }\end{array}$ \\
\hline 4. & Pasal 83 & $\begin{array}{l}\text { Pekerja/buruh perempuan yang anaknya masih menyusu harus diberi } \\
\text { kesempatan sepatutnya untuk menyusui anaknya jika hal itu harus } \\
\text { dilakukan selama waktu kerja. }\end{array}$ \\
\hline 5. & Pasal 84 & $\begin{array}{l}\text { Setiap pekerja/buruh yang menggunakan hak waktu istirahat } \\
\text { sebagaimana dimaksud dalam Pasal } 79 \text { ayat (2) huruf b, c, dan d, } \\
\text { Pasal 80, dan pasal } 82 \text { berhak mendapatkan upah penuh. }\end{array}$ \\
\hline 6. & Pasal 93 & $\begin{array}{l}\text { 2) ..............Pengusaha wajib membayar upah apabila: } \\
\text { b. Pekerja/buruh perempuan yang sakit pada hari pertama dan } \\
\text { kedua masa haidnya sehingga tidak dapat melakukan } \\
\text { pekerjaan. } \\
\text { c. Pekerja/buruh tidak masuk bekerja karena pekerja/buruh } \\
\text { menikah, menikahkan, mengkhitankan, membaptiskan } \\
\text { anaknya, istri melahirkan atau keguguran kandungan, suami } \\
\text { atau istri atau anak atau menantu atau orang tua atau mertua } \\
\text { atau anggota keluarga dalam satu rumah meninggal dunia. } \\
\text { 4) Upah yang dibayarkan kepada pekerja/buruh yang tidak masuk } \\
\text { bekerja sebagaimana dimaksud dalam ayat } 2 \text { huruf c sebagai } \\
\text { berikut: } \\
\text { e. istri melahirkan atau keguguran kandungan, dibayar untuk } \\
\text { selama } 2 \text { (dua) hari. }\end{array}$ \\
\hline 7 & Pasal 153 & $\begin{array}{l}\text { (1) Pengusaha dilarang melakukan pemutusan hubungan kerja } \\
\text { dengan alasan: } \\
\text { e. Pekerja/buruh perempuan hamil, melahirkan, gugur } \\
\text { kandungan, atau menyusui bayinya; }\end{array}$ \\
\hline 8 & Pasal 185 & $\begin{array}{l}\text { (1) Barangsiapa melanggar ketentuan sebagaimana dimaksud dalam } \\
\text { Pasal } 42 \text { ayat (1) dan ayat (2), Pasal 68, Pasal } 69 \text { ayat (2), Pasal } \\
\text { 80, Pasal 82, Pasal } 90 \text { ayat (1), Pasal 143, dan Pasal } 160 \text { ayat (4) }\end{array}$ \\
\hline
\end{tabular}




\begin{tabular}{|c|c|c|}
\hline & & $\begin{array}{l}\text { dan ayat (7), dikenakan sanksi pidana penjara paling singkat } 1 \\
\text { (satu) tahun dan paling lama } 4 \text { (empat) tahun dan/atau denda } \\
\text { paling sedikit Rp. } 100.000 .000,00 \text { (seratus juta rupiah) dan paling } \\
\text { banyak Rp. } 400.000 .000,00 \text { (empat ratus juta rupiah). }\end{array}$ \\
\hline 9 & Pasal 186 & $\begin{array}{l}\text { (1) Barangsiapa melanggar ketentuan sebagaimana dimaksud dalam } \\
\text { Pasal } 35 \text { ayat (2) dan ayat (23), Pasal } 93 \text { ayat (2), Pasal 137, dan } \\
\text { Pasal } 138 \text { ayat (1), dikenakan sanksi pidana penjara paling singkat } \\
4 \text { (empat) tahun dan paling lama } 4 \text { (empat) tahun dan/atau denda } \\
\text { paling sedikit Rp. } 10.000 .000,00 \text { (sepuluh juta rupiah) dan paling } \\
\text { banyak Rp. } 400.000 .000,00 \text { (empat ratus juta rupiah). }\end{array}$ \\
\hline 10 & Pasal 187 & $\begin{array}{l}\text { (1) Barangsiapa melanggar ketentuan sebagaimana dimaksud dalam } \\
\text { Pasal } 37 \text { ayat (2), Pasal } 44 \text { ayat (1), Pasal } 45 \text { ayat (1), Pasal } 67 \\
\text { ayat (1), Pasal } 71 \text { ayat (2), Pasal 76, Pasal } 78 \text { ayat (2), Pasal } 79 \\
\text { ayat (1) dan ayat (2), Pasal } 85 \text { ayat (3), dan Pasal 144, dikenakan } \\
\text { sanksi pidana kurungan paling singkat } 1 \text { (satu) bulan dan paling } \\
\text { lama } 12 \text { (dua belas) bulan dan/atau denda paling sedikit Rp. } \\
10.000 .000,00 \text { (sepuluh juta rupiah) dan paling banyak Rp. } \\
100.000 .000,00 \text { (seratus juta rupiah). }\end{array}$ \\
\hline
\end{tabular}

Tabel di atas menunjukkan bahwa Undang-Undang no. 13 tahun 2003 telah memuat aturan mengenai perlindungan kesehatan reproduksi bagi pekerja perempuan baik secara langsung ataupun tidak langsung. Dalam undang-undang ini, aturan yang secara langsung menjelaskan tentang perlindungan kesehatan reproduksi bagi pekerja perempuan meliputi cuti haid, tidak bekerja pada malam hari ketika sedang hamil, kesempatan untuk menyusui, cuti melahirkan dan nifas, dan cuti gugur kandungan yang termaktub dalam pasal 76 ayat 2, pasal 81 ayat 1, Pasal 82 ayat 1 dan ayat 2, dan Pasal 83. Adapun pasal-pasal lainnya yaitu Pasal 84, pasal 93 ayat 2 dan ayat 4, Pasal 153 ayat 1, pasal 185 ayat 1, Pasal 186 ayat 1 , dan pasal 187 ayat 1 merupakan pendukung dari perlindungan kesehatan reproduksi bagi pekerja perempuan dalam pasal-pasal sebelumnya. Untuk lebih jelasnya, beberapa hak kesehatan reproduksi bagi pekerja perempuan yang termaktub dalam kebijakan ini adalah sebagai berikut:

Tabel 2. Hak-Hak Kesehatan Reproduksi bagi Pekerja Perempuan dalam UndangUndang No. 13 tahun 2003 tentang Ketenagakerjaan

\begin{tabular}{|c|c|c|}
\hline No & $\begin{array}{c}\text { Kesehatan } \\
\text { Reproduksi bagi }\end{array}$ & Hak-Hak Yang Didapat Pekerja Perempuan \\
\hline
\end{tabular}




\begin{tabular}{|c|c|c|}
\hline & $\begin{array}{l}\text { Pekerja Perempuan } \\
\text { Yang dilindungi }\end{array}$ & \\
\hline 1. & Cuti Haid & $\begin{array}{l}\text { - Istirahat pada hari pertama dan kedua pada masa } \\
\text { haid } \\
\text { - Mendapatkan upah penuh } \\
\text { - Jika dilanggar, maka pengusaha akan dikenakan } \\
\text { sanksi pidana penjara paling singkat } 4 \text { (empat) } \\
\text { tahun dan paling lama } 4 \text { (empat) tahun dan/atau } \\
\text { denda paling sedikit Rp. 10.000.000,00 (sepuluh } \\
\text { juta rupiah) dan paling banyak Rp. } 400.000 .000,00 \\
\text { (empat ratus juta rupiah). }\end{array}$ \\
\hline 2. & Hamil & $\begin{array}{l}\text { - Tidak bekerja pada pukul } 23.00-07.00 \\
\text { - Jika dilanggar, maka pengusaha dikenakan sanksi } \\
\text { pidana kurungan paling singkat } 1 \text { (satu) bulan dan } \\
\text { paling lama } 12 \text { (dua belas) bulan dan/atau denda } \\
\text { paling sedikit Rp. } 10.000 .000,00 \text { (sepuluh juta } \\
\text { rupiah) dan paling banyak Rp. } 100.000 .000,00 \\
\text { (seratus juta rupiah). }\end{array}$ \\
\hline 3. & $\begin{array}{l}\text { Melahirkan dan masa } \\
\text { nifas }\end{array}$ & $\begin{array}{l}\text { - Istirahat selama } 1,5 \text { bulan sebelum dan } 1,5 \text { bulan } \\
\text { sesudah melahirkan } \\
\text { - Mendapatkan upah penuh } \\
\text { - Dapat diperpanjang baik sebelum melahirkan } \\
\text { maupun sesudah melahirkan berdasarkan surat } \\
\text { keterangan dari dokter atau bidan. } \\
\text { - Suami yang istrinya melahirkan mendapatkan } \\
\text { waktu istirahat selama dua hari dan berhak } \\
\text { mendapatkan upah penuh } \\
\text { - Jika dilanggar, maka pengusaha akan mendapatkan } \\
\text { sanksi pidana penjara paling singkat } 1 \text { (satu) tahun } \\
\text { dan paling lama } 4 \text { (empat) tahun dan/atau denda } \\
\text { paling sedikit Rp. 100.000.000,00 (seratus juta } \\
\text { rupiah) dan paling banyak Rp. 400.000.000,00 } \\
\text { (empat ratus juta rupiah). } \\
\text { - Jika hak upahnya tidak berikan, maka pengusaha } \\
\text { akan dikenakan sanksi pidana penjara paling } \\
\text { singkat } 4 \text { (empat) tahun dan paling lama } 4 \text { (empat) } \\
\text { tahun dan/atau denda paling sedikit Rp. } \\
\text { 10.000.000,00 (sepuluh juta rupiah) dan paling } \\
\text { banyak Rp. 400.000.000,00 (empat ratus juta } \\
\text { rupiah). }\end{array}$ \\
\hline 4. & Keguguran kandungan & $\begin{array}{l}\text { - Istirahat } 1,5 \text { bulan atau sesuai dengan surat } \\
\text { keterangan dokter kandungan atau bidan } \\
\text { - Mendapatkan upah penuh } \\
\text { - Suami yang istrinya mengalami keguguran } \\
\text { mendapatkan waktu istirahat selama dua hari dan } \\
\text { berhak mendapatkan upah penuh }\end{array}$ \\
\hline
\end{tabular}




\begin{tabular}{|c|c|c|}
\hline & & $\begin{array}{l}\text { - Jika hak upahnya tidak diberikan, maka pengusaha } \\
\text { akan dikenakan sanksi pidana penjara paling } \\
\text { singkat } 4 \text { (empat) tahun dan paling lama } 4 \text { (empat) } \\
\text { tahun dan/atau denda paling sedikit Rp. } \\
10.000 .000,00 \text { (sepuluh juta rupiah) dan paling } \\
\text { banyak Rp. } 400.000 .000,00 \text { (empat ratus juta } \\
\text { rupiah). }\end{array}$ \\
\hline 5. & Masa menyusui & $\begin{array}{l}\text { - Kesempatan sepatutnya untuk menyusui anaknya } \\
\text { jika hal itu harus dilakukan selama waktu kerja. }\end{array}$ \\
\hline
\end{tabular}

Secara sepintas, dengan adanya perlindungan terhadap kesehatan reproduksi tersebut, undang-undang no. 13 tahun 2003 tentang ketenagakerjaan ini nampak telah memenuhi kebutuhan dan kepentingan perempuan terkait dengan kesehatan reproduksinya yang berbeda dengan laki-laki. Tetapi, jika dianalisa dengan menggunakan pendekatan hukum berperspektif perempuan, rumusan mengenai perlindungan kesehatan reproduksi bagi pekerja perempuan dalam undang-undang ini masih mempunyai beberapa kelemahan.

Pertama, terbatasnya pelayanan atau fasilitas yang mendukung terlaksananya perlindungan kesehatan reproduksi bagi pekerja perempuan. Kedua, masih terdapat kesehatan reproduksi bagi perempuan yang belum diatur dalam undang-undang ini, seperti pelayanan keluarga berencana. Ketiga, aturan tersebut dalam beberapa hal sebenarnya justru tidak memberikan kepastian hukum bagi perempuan untuk mendapatkan perlindungan kesehatan reproduksinya. Kelemahan dalam aturan tentang perlindungan kesehatan reproduksi bagi pekerja perempuan tersebut selanjutnya dapat membuka peluang bagi pengusaha untuk tidak memberikan perlindungan kesehatan reproduksi kepada pekerja perempuannya. Untuk lebih jelasnya, berikut adalah beberapa analisa mengenai kelemahan dan keterbatasan aturan tentang perlindungan kesehatan reproduksi bagi pekerja perempuan dalam Undang-Undang no. 13 tahun 2003 tentang ketenagakerjaan.

\section{Pekerja Perempuan yang sedang haid}

Jika dilihat secara lebih mendalam, untuk mendapatkan perlindungan terhadap kesehatan reproduksinya ketika sedang mengalami haid, pekerja perempuan disyaratkan untuk memberitahukan kepada pengusaha dan berlaku bagi pekerja perempuan yang merasakan sakit pada hari pertama dan kedua ketika haid. Pemberlakuan syarat yang demikian dapat memberikan peluang kepada pengusaha untuk tidak memberikan perlindungan kepada pekerja perempuan untuk mendapatkan cuti haid dengan beberapa alasan atau kondisi. 
a. Bagi pekerja perempuan yang tidak mempunyai pengetahuan tentang adanya hak untuk mengajukan cuti haid akan diam saja dan tidak melakukan pengajuan sehingga kehilangan salah satu hak kesehatan reproduksinya.

b. Bagi pekerja perempuan yang mengetahui haknya untuk mengajukan cuti tetapi tidak memiliki keberanian untuk menyampaikan juga akan diam saja dan tidak melakukan pengajuan sehingga kehilangan haknya untuk memeperoleh cuti haid.

c. Bagi pekerja perempuan yang mengetahui haknya dan berani mengajukan cuti haid tetapi pada hari pertama dan hari kedua ia tidak merasakan sakit, maka ia tidak akan mengajukan cuti haid.

d. Bagi pekerja perempuan yang merasakan sakit pada hari pertama dan kedua ketika haid "dapat dikondisikan atau ditekan" untuk tidak merasa sakit sehingga ia tetap bekerja.

\section{Pekerja perempuan yang sedang hamil}

Apabila dianalisis lebih dalam. pekerja perempuan yang sedang mengalami kehamilan masih belum sepenuhnya mendapatkan perlindungan. Dalam Pasal 76 undang-undang ini, perlindungan dalam bentuk larangan bekerja pada pukul 23.00-07.00 disyaratkan bagi kehamilan yang membahayakan menurut keterangan dokter atau bidan sehingga memunculkan beberapa kelemahan dan persepsi yang dapat melemahkan perlindungan terhadap pekerja perempuan yang sedang hamil.

Pertama, aturan tersebut tidak mengatur tentang batasan berapa usia kehamilan bagi pekerja perempuan untuk mulai mendapatkan hak tidak bekerja pada malam hari. Kedua, kondisi yang membahayakan bagi orang hamil untuk tidak bekerja pada malam hari pada pasal ini didasarkan pada keterangan dokter atau bidan. Sementara, pekerja perempuan yang sedang hamil tidak mungkin memeriksakan dirinya setiap hari ke dokter atau bidan. Kondisi ini dapat menyebabkan pekerja perempuan yang sedang hamil dan dalam kondisi kehamilan yang membahayakan sebelum diperiksa oleh dokter atau bidan akan tetap bekerja pada waktu malam. Ketiga, aturan tersebut tidak menjelaskan tentang larangan bagi pengusaha untuk mempekerjakan pekerja perempuan yang sedang hamil di berbagai bagian pekerjaan lainnya yang dapat membahayakan bagi kehamilannya.

\section{Pekerja Perempuan yang sedang melahirkan dan nifas}

Undang-Undang No. 13 tahun 2003 tentang ketenagakerjaan telah menjelaskan perlindungan kesehatan reproduksi bagi pekerja perempuan yang melahirkan dan sedang 
mengalami nifas. Perlindungan kesehatan reproduksi yang diberikan adalah berupa istirahat selama 1,5 bulan menjelang kelahiran dan 1,5 setelah melahirkan (pada masa nifas). Selama masa istirahat baik 1,5 bulan sebelum melahirkan dan 1,5 bulan setelah melahirkan, pekerja perempuan masih mempunyai hak untuk mendapatkan upahnya secara penuh. Tidak hanya itu, bahkan jika dalam kondisi yang belum memungkinkan atau membahayakan pekerja perempuan mempunyai hak untuk mengajukan perpanjangan waktu istirahat baik sebelum melahirkan atau setelah melahirkan berdasarkan keterangan dokter atau bidan.

Perlindungan mengenai perempuan yang melahirkan nampak telah diatur dengan beberapa kemudahan dan berbagai haknya mulai hak yang didapat oleh pekerja perempuan maupun suaminya. Hanya saja, dalam undang-undang ini tidak diatur mengenai tunjangan yang didapat oleh pekerja perempuan yang sedang melahirkan. Padahal, untuk melahirkan, ia akan membutuhkan banyak biaya.

\section{Pekerja perempuan yang sedang menyusui}

Secara sepintas, aturan tersebut memang memenuhi kepentingan dan kebutuhan pekerja perempuan untuk menyusui anaknya. Namun, jika dicermati secara lebih mendalam, aturan masih lemah dalam melindungi hak pekerja perempuan untuk menyusui anaknya.

Dalam penjelasan undang-undang ini telah dinyatakan bahwa yang dimaksud dengan "kesempatan sepatutnya" adalah lamanya waktu yang diberikan kepada pekerja perempuan untuk menyusui bayinya dengan memperhatikan tersedianya tempat yang sesuai dengan kondisi dan kemampuan perusahaan yang diatur dalam peraturan perusahaan atau perjanjian kerja bersama. Hal ini menyiratkan bahwa perusahaan harus menyediakan tempat untuk menyusui bayi atau tempat penitipan anak.

Dalam realitanya, masih banyak perusahaan yang tidak menyediakan fasilitas tersebut. Akibatnya, pekerja perempuan akan kesulitan untuk menyusui bayinya karena makna dalam redaksi "kesempatan sepatutnya" memunculkan banyak persepsi. Persepsi pengusaha adalah bagaimana pekerja perempuan dapat menyusui anaknya dengan waktu yang relatif singkat untuk menjaga hasil produksi perusahaan. Jika pekerja perempuan tidak memenuhinya dalam waktu singkat ia bisa mendapatkan tekanan dalam berbagai bentuk seperti bentakan, marah, atau bahkan hukuman. Sementara, pekerja perempuan tinggal di luar arena pabrik sehingga memerlukan banyak waktu untuk pulang pergi dan menyusui anaknya. Kondisi ini, tentu saja dapat menyebabkan pekerja perempuan kesulitan untuk mengakses hak menyusui anaknya.

\section{Pekerja perempuan yang mengalami Keguguran}

Jika dilihat secara lebih mendalam, aturan mengenai perlindungan terhadap pekerja perempuan untuk cuti keguguran ini tidak mencantumkan penjelasan mengenai berapa usia 
kehamilan saat mengalami keguguran sehingga memunculkan banyak persepsi. Tidak diaturnya hal itu dapat membuka peluang pengusaha untuk menggunakan persepsinya sendiri mengenai segala hal yang terkait dengan cuti keguguran, meliputi usia kehamilan saat mengalami keguguran, lamanya waktu cuti dan upah yang seharusnya diterima oleh pekerja perempuan yang sedang mengalami keguguran. Lebih jauh lagi, dalam undang-undang ini juga tidak diatur tentang tunjangan bagi pekerja perempuan yang sedang mengalami keguguran. Padahal dalam praktiknya, pekerja perempuan yang sedang mengalami gugur kandungan juga harus mengeluarkan biaya kesehatan.

\section{Implementasi Kebijakan Perlindungan Kesehatan Reproduksi Perempuan dalam Undang-Undang No. 13 tahun 2003 tentang Ketenagakerjaan}

Terkait dengan implementasi kebijakan perlindungan kesehatan reproduksi dalam Undang-Undang no. 13 tahun 2003 tentang Ketenagakerjaan, pekerja perempuan tidak serta merta mendapatkan haknya sebagaimana yang sudah tercantum dalam Undang-Undang tersebut. Perusahaan kadang-kadang mempunyai interpretasi yang berbeda dengan kebijakan yang ada sehingga hak-hak yang seharusnya diterima oleh pekerja perempuan terkait dengan perlindungan kesehatan reproduksinya menjadi sulit digunakan oleh pekerja perempuan. Sulitnya pekerja perempuan dalam mengakses perlindungan terhadap kesehatan reproduksinya ditemukan oleh penulis dalam berbagai penelitian yang sudah dilakukan sebagai berikut.

\section{Implementasi hak cuti haid}

Beberapa penelitian telah menunjukkan temuan bahwa implementasi perlindungan kesehatan reproduksi dalam hak cuti haid berbeda dengan yang terdapat dalam aturan di Undang-undang no. 13 tahun 2003 tentang ketenagakerjaan. Beberapa temuan terkait dengan hal ini antara lain, sebelum undang-undang ini disahkan ditemukan bahwa untuk mengambil cuti haid, pekerja perempuan harus melewati prosedur yang tidak mudah, bahkan cenderung melecehkan pekerja perempuan sebagaimana penjelasan berikut.

"Pada PT A, Cimanggis, Bogor, meskipun dalam KKB pekerja perempuan mendapatkan cuti haid selama dua hari, banyak buruh yang tidak mau mengambil izin cuti karena diharuskan membuka celana dalamnya di hadapan petugas untuk menunjukkan bahwa pekerja perempuan yang bersangkutan benar-benar haid." (Hasil temuan Nurbiati dan Edriana, 1991 sebagaimana dikutip dalam Safa'at 1998).

Masih dalam penelitian sebelumnya, Safa'at (1998) menyatakan bahwa banyak perusahaan industri memberikan sejenis insentif, seperti premi prestasi dan bonus-bonus 
lainnya yang dikaitkan dengan kehadiran pekerja secara fisik di tempat kerja. Pemberian insentif tersebut akan hilang dengan sendirinya jika pekerja tidak hadir meski dalam sehari. Oleh karena itu, pekerja perempuan berusaha agar tetap hadir meskipun ia sedang mengalami sakit akibat haid. Pernyataan tersebut didukung oleh hasil temuan Indraswari dan Thamrin pada pekerja perempuan di perusahaan industri tembakau di Jember (1993).

Meskipun telah hadir undang-undang no. 13 tahun 2003 tentang ketenagakerjaan yang memuat aturan tentang cuti haid, namun pelekasanaannya ternyata masih tidak jauh beda dengan kondisi sebelumnya. Beberapa hasil penelitian menunjukkan sebagai berikut.

Hasil penelitian Maimunah (2008) menyatakan bahwa pekerja perempuan di perusahaan B, di KBN Cakung, mengaku tetap bekerja pada hari pertama dan hari kedua pada saat haid. Namun, mereka mengaku mendapatkan upah dua kali lipat sebagai ganti waktu istirahat yang bisa didapatkan.

Dalam penelitiannya di perusahaan yang lain yaitu di perusahaan X di KBN Tanjung Priok juga ditemukan pekerja perempuan yang mengaku tetap bekerja pada hari pertama dan hari kedua pada saat haid dan mendapatkan upah dua kali lipat.

"Buruh-buruh perusahaan X berhak mendapat cuti haid selama dua hari. Namun, perusahaan "merekayasa" sedemikian rupa hak cuti haid selama dua hari itu dengan uang senilai Rp. 34.402 per hari. Uang "pengganti" itu diberikan kepada pekerja yang tetap masuk kerja meskipun sedang haid. Pekerja dirangsang dengan uang untuk tidak mengambil hak cuti haid. Artinya, pekerja yang tetap masuk kerja meski haid mendapat "upah ganda" yakni upah harian dan uang pengganti cuti haid dua hari, sedangkan pekerja yang mengambil cuti haid hanya mendapatkan upah harian." (Berdasarkan hasil penelitian Maimunah, 2008)

Hasil-hasil penelitian di atas menunjukkan bahwa pengusaha cenderung melakukan berbagai upaya untuk menjaga hasil produksinya. Terkait dengan hal ini pengusaha memberikan dua kali upah jika pekerja perempuan yang merasakan sakit pada hari pertama dan hari kedua haid tetap masuk kerja. Pemberlakuan dua kali upah ini seolah-olah adalah tidak ada pemaksaan dari pihak pengusaha. Pengusaha seolah-olah memberikan pilihan bagi pekerja perempuan. Tetapi sesungguhnya pengusaha dalam hal ini menggunakan kekuatan ekonominya untuk "menekan secara halus" pekerja perempuan yang memang dalam kondisi sangat tidak berdaya karena kondisi ekonominya.

2. Implementasi hak pekerja perempuan hamil untuk tidak bekerja pada pukul 23.0007.00

Dalam pelaksanaannya di lapangan, aturan tentang perlindungan pekerja perempuan yang hamil dilarang bekerja antara pukul 23.00-07.00 WIB, tidak serta-merta diterima oleh 
pekerja perempuan dengan kondisi di atas. Kondisi tersebut ditunjukkan dalam penelitian Maimunah (2008) bahwa pekerja perempuan yang sudah hamil diatas 7 bulan tetap bekerja pada jam malam, yaitu pada pukul $23.00-07.00$.

"Ika mengatakan bahwa pihak managemen perusahaan melalui chief kerap menutup mata, bahkan mnegatakan, "Kalau masih kuat ya biarin aja, karena nggak ada yang gantiin”. (Maimunah, 2008)

Belum terlindunginya pekerja perempuan yang sedang hamil, juga ditemukan oleh (Suzianni, 2007) dalam penelitiannya sebagai berikut.

"Dalam kenyataannya, buruh perempuan yang hamil atau menyusui di PT. C bekerja lembur sampai pukul 21.00 WIB atau pukul 03.00 WIB dinihari atau bekerja berdasarkan shift; bekerja mendorong-dorong gerobak hingga mengalami pendarahan seperti yang dialami Sisi, karena tidak dipindahkan ke tempat yang lebih ringan jenis pekerjaannya; atau bekerja lebih banyak berdiri, seperti di bagian $Q C$ Line, sehingga buruh yang sedang hamil meminjam atau 'mencuri-curi' tempat duduk buruh lain yang bekerja sambil duduk di bagian jahit, bila buruh tersebut sedang ke kakus atau sholat, seperti yang dialami Minah.” (Berdasarkan hasil penelitian Suzianni, 2007)

Hasil wawancara di atas serta temuan penelitian di atas menunjukkan lemahnya posisi pekerja perempuan yang tidak mempunyai bargaining power akibat tidak mempunyai kekuasaan, dalam hal ini ekonomi. Pekerja perempuan dalam kondisi keterbatasan ekonomi tetap berupaya untuk masuk kerja meskipun mempunyai hak untuk istirahat karena harus mengejar uang untuk menutupi kebutuhan keluarganya. Lemahnya posisi pekerja perempuan ini berbanding terbalik dengan kepentingan perusahaan untuk tetap meningkatkan produksinya. Apalagi, jika ketidakhadiran pekerja perempuan tidak ada yang menggantikan sehingga berpengaruh terhadap hasil produksi perusahaan. Akhirnya, perusahaan pun tetap mempekerjakan pekerja perempuan hamil dengan usia kandungan 7 bulan lebih yang dalam pandangan dokter sudah termasuk dalam kondisi membahayakan pada pukul 23.00-07.00.

\section{Implementasi hak cuti melahirkan dan nifas}

Ketika sedang hamil dan hendak melahirkan, dalam realitanya masih banyak pekerja perempuanyang tidak dapat mendapatkan perlindungan kesehatan reproduksinya. Berikut adalah hasil temuan penelitian Suzianni (2007) tentang dinamika pekerja perempuan yang tidak mendapatkan perlindungan berupa cuti melahirkan sebagaimana yang tercantum dalam aturan undang-undang ini.

a. Berdasarkan kisah Rina, sebagaimana dipaparkan oleh Suzianni (2007).

"Pada bulan Agustus 2006, usia kehamilannya mencapai delapan bulan. Berarti sebulan lagi masa kontraknya akan berakhir tepat setelah selama 
setahun masa perpanjangan yang keempat kali. Akan tetapi, seperti yang terjadi pada buruh perempuan tetap yang hamil lainnya yang diminta untuk cuti, Rina pun diminta menghentikan kegiatannya. Pihak personalia memintanya untuk menyelesaikan masa kontraknya itu pada usia kehamilannya yang kedelapan, yakni bulan Agustus 2006. Bulan September 2006, atas keputusan sepihak dari personalia perusahaan tersebut, ia dibebaskan dari statusnya sebagai buruh kontrak di PT. C dengan mendapat upahnya selama bulan tersebut."

b. Berdasarkan kisah Ningsih, sebagaimana dipaparkan oleh Suzianni (2007)

"Maka, ketika kandungannya memiliki cukup waktu untuk cuti melahirkan (8 bulan), yaitu ketika masa kontraknya masih sisa satu bulan, ia dipanggil oleh Personalia. Menurut Personalia, masa kontraknya sudah habis dan tidak akan diperpanjang. Hubungan kerjanya diputus atau dihabiskan secara sepihak dan dibayar sampai habis masa kontraknya 9 bulan alias tidak diperpanjang, sehingga ia tidak mendapatkan haknya berupa cuti melahirkan dan upahnya selama tiga bulan."

Kedua cerita di atas, menunjukkan bahwa pengusaha mempunyai berbagai macam cara untuk tidak memberikan perlindungan berupa hak cuti melahirkan kepada pekerja perempuan. Dengan alasan mempekerjakan pekerja perempuan sebagai buruh kontrak, perusahaan seolah-olah terbebaskan dari aturan karena dalam undang-undang tersebut tidak dijelaskan secara terperinci mengenai status kerja dari pekerja perempuan tersebut.

\section{Implementasi hak kesempatan menyusui}

Dalam realitasnya, pekerja perempuan yang masih dalam masa menyusui sulit mendapatkan haknya untuk menyusui anaknya pada jam kerja. Hal ini disebabkan oleh tidak adanya fasilitas penitipan anak. Sementara, tempat tinggal mereka agak jauh dari perusahaan tempat bekerja sehingga membutuhkan waktu yang agak lama. Kondisi ini menyebabkan mereka kesulitan untuk menyusui anaknya. Kondisi tersebut sama dengan hasil temuan Suzianni (2007) sebagai berikut.

"Setelah cuti, ia bekerja kembali di perusahaan tersebut dengan status masih sebagai buruh kontrak. ASInya normal. Bahkan terlalu banyak, sehingga pada saat bekerja ia harus membuang ASInya yang melimpah itu di kakus. Air susu ditampung dulu di dalam plastik ketika istirahat, kemudian minta ke kakus dan membuang air susu ibunya di sana. Karena telah lama ia tidak menyusui bayinya dengan ASInya sendiri disebabkan tidak ada waktu untuk menyusui selama bekerja, kini ASInya mengering dan tidak dapat menyusui lagi bayinya dengan ASInya."

Dalam kasus yang lain, sulitnya pekerja perempuan menggunakan haknya untuk menyusui tergambar dalam kasus sebagai berikut.

"Pada hari pertama Ningsih bekerja, ia merasakan badannya demam dan panas-dingin, karena payudaranya banjir disebabkan ASInya keluar sangat 
banyak. Karena tidak kuat, maka ia minta kartu antri ke kakus kepada Satpam dengan alasan ingin buang air kecil. Di kakus, ia memeras kedua payudaranya. Air susunya dimasukkannya ke dalam gayung dan kemudian dibuangnya di lubang kakus. Lubang kakus disiramnya sampai bersih untuk menghilangkan jejak. Sekarang, payudaranya disumbat dengan kain basah, agar ASInya tidak keluar (banyak). Ketika pulang ke rumah, payudaranya ia bersihkan atau dilap dengan air hangat lalu ia pun menyusui bayinya. Ia hanya menyusui pada pagi hari sebelum pergi bekerja dan malam hari setelah bekerja ditambah dengan susu formula”. (Berdasarkan temuan Suzianni pada tahun 2007).

Cerita di atas menunjukkan bahwa perusahaan tidak memberikan akses bagi pekerja perempuan yang sedang dalam masa menyusui untuk menggunakan haknya. Hal ini terbukti dengan tidak disediakan ruangan penitipan bayi di sekitar pabrik. Sementara, untuk memenuhi hak menyusuinya, pekerja perempuan dilarang meninggalkan pabrik dalam masa yang lama karena dikejar oleh target yang harus diselesaikan. Jika target tidak terselesaikan, ia akan kena marah dan hukuman. Kesulitan pekerja perempuan untuk meminta izin tergambar dari kisah di atas, dimana pekerja dijaga oleh satpam ketika bekerja dan harus meminta ijin meskipun hanya untuk ke kamar mandi, apalagi harus meminta ijin pulang untuk menyusui anaknya.

\section{Implementasi hak cuti keguguran}

Pelaksanaan hak cuti keguguran bagi pekerja perempuan juga tidak serta-merta dapat digunakan oleh pekerja perempuan yang mengalami keguguran. Hal ini dibuktikan dengan adanya temuan penelitian oleh Maimunah (2008) mengenai pekerja perempuan yang mengalami keguguran tidak mendapatkan cuti selama 1,5 bulan sebagaimana yang terdapat dalam peraturan. Tidak hanya itu, ia juga tidak mendapatkan upah penuh selama 1,5 bulan. Ia hanya diberi uang santunan ala kadarnya. Bahkan, ia tidak dianggap sedang mengalami gugur kandungan sebagaimana yang dimaksud dalamUndang-Undang oleh personalia karena gugur kandungan yang dimaksudkan dalam Undang-Undang adalah gugur kandungan bagi usia kehamilan di atas 4 bulan. Untuk lebih jelasnya, simak kisah berikut.

"Kalau kamu masih ingin cuti hingga hak cuti kamu habis, kamu harus menyediakan surat dokter lagi dari dokter yang pertama ketika gugur kandungan. Surat terebut harus menerangkan bahwa kamu masih harus istirahat hingga sisa cuti berakhir. Jika tidak ada surat tersebut, maka kau harus masuk kerja. Kalau tidak masuk, kamu tidak akan diberi gaji”.

"Perusahaan memang memberi uang 750 ribu rupiah sebagai "pengganti" seluruh biaya kuret. Namun biaya itu masih jauh di bawah seluruh biaya yang telah dikeluarkannya, yaitu sebesar 2,5 juta rupiah untuk kuret, USG, dan obatobatannya."

"Perusahaan juga berpendpat bahwausia janin Enong pada saat keguguran belum terlalu besar (dua bulan) dan belum "bernyawa". Dengan kata lain, 
Enong dianggap tidak mengalami keguguran. Menurut bagian personalia, keguguran yang dimaksud dalam aturan undang-undang adalah keguguran pada usia kehamilan di atas empat bulan“".

\section{Pemenuhan Hak Kesehatan Reproduksi Vs Kepentingan Ekonomi}

Kesulitan pekerja perempuan dalam mengakses hak-hak kesehatan reproduksinya disebabkan oleh beberapa hal. Pertama, pengetahuan dan pemahaman pekerja perempuan mengenai hak-hak kesehatan reproduksinya sebagaimana yang sudah tercantum dalam Undang-Undang no. 13 tahun 2003 tentang Ketenagakerjaan. Kedua, lemahnya kesadaran pekerja perempuan untuk memperjuangkan hak-hak kesehatan reproduksinya. Ketiga, lemahnya bargaining power pekerja perempuan akibat tidak mempunyai kekuasaan ekonomi). Kondisi ketiga inilah yang lebih banyak dialami oleh pekerja perempuan karena pekerja perempuan yang sudah mempunyai pengetahuan, pemahaman, dan kesadaran tetap harus berhadapan dengan kekuasaan ekonomi.

Kesulitan pekerja perempuan dalam mengakses perlindungan kesehatan reproduksinya sebagaimana gambaran kisah-kisah di atas, menurut feminisme marxis, terjadi melalui produk politik, sosial, dan struktur ekonomi yang berkaitan erat dengan sistem kapitalisme, yaitu suatu sistem yang menimbulkan terjadinya pertentangan antara kelas proletariat yang dieksploitasi oleh kelas borjuis sebagai kelas yang memiliki modal (Tong, 1998). Dalam kasus ini, para pekerja perempuan menempati posisi yang lemah, tidak mempunyai kekuasaan, dan bargaining power yang tinggi dengan pemilik modal sehingga mereka tidak mempunyai pilihan lain kecuali menerima kondisi untuk dieksploitasi. Pekerja perempuan mendapatkan paradigma bahwa hubungan pemilik modal-buruh adalah hubungan pertukaran modal dan tenaga. Paradigma tersebut selanjutnya memunculkan kondisi bahwa pekerja perempuan yang tidak mempunyai kekuatan modal seolah-olah bersifat "sukarela" melakukan apa saja untuk peningkatan hasil ekonomi dengan menafikan hak-hak yang seharusnya didapatnya.

Dilihat dari perspektif feminis radikal, akar kekerasan terhadap perempuan terjadi karena adanya sistem gender yang merugikan perempuan, yaitu patriarki. Bhasin (1996) mengatakan bahwa patriarki merupakan suatu sistem dimana laki-laki mendominasi dalam ranah ekonomi, sosial, dan budaya, sedangkan perempuan tersubordinasi berbagai ranah tersebut. Namun, satu hal yang perlu untuk diperhatikan adalah bahwa kekuasaan laki-laki yang dimaksud dalam sistem patriarki dapat berupa manusia yang berjenis kelamin laki-laki atau perempuan. 
Sistem yang demikian telah terbentuk sejak berabad-abad tahun yang lalu hingga pada masa sekarang bahkan telah mengental dalam berbagai produk hukum dan kebijakan. Tidak terkecuali adalah kebijakan undang-undang no. 13 tahun 2003 tentang ketenagakerjaan. Pada implementasi berikutnya, nilai-nilai patriarki tersebut kemudian melahirkan berbagai bentuk ketidakadilan terhadap perempuan selain kekerasan, yaitu stereotip, beban kerja, marginalisasi, subordinasi, dan eksploitasi, serta kekerasan terhadap perempuan.

Dalam kaitannya dengan penelitian ini, pekerja perempuan merupakan kelompok yang sangat rentan dengan diskriminasi karena beberapa hal. Pertama, pekerja perempuan adalah kelompok buruh yang mewakili kelas bawah yang tidak mempunyai kekuasaan dan tidak diikutsertakan dalam proses pembuatan kebijakan. Meskipun kebijakan atau aturan tersebut sangat berkaitan dengan keberadaan dirinya. Kedua, pekerja perempuan adalah kelompok kelas perempuan yang dikonstruksikan sebagai kelompok yang tidak memiliki bargaining power karena partisipasinya dalam dunia industri dianggap sebagai pendukung suami dalam mencari nafkah. Ketiga, pekerja perempuan merupakan kelompok yang keberadaannya dianggap merugikan pengusaha karena berbagai kondisi alat reproduksi yang dimilikinya.

Dengan mengacu pada berbagai kisah pekerja perempuan di atas, dapat dinyatakan bahwa rumusan kebijakan Undang-Undang ketenegakerjaan ini yang telah dibuat cenderung mengabaikan pengalaman, kebutuhan, dan kepentingan perempuan. Kebutuhan dan kepentingan yang terabaikan adalah berupa seluruh kebutuhan perempuan terkait dengan keberadaan dan fungsi reproduksinya yang berbeda dengan laki-laki. Termasuk juga dalam hal ini adalah segala hal yang merupakan implikasi dari keberadaan dan fungsi reproduksinya. Maka sudah dapat dipastikan kelanjutnya, apabila sebuah rumusan aturan telah mengabaikan kebutuhan dan kepentingan perempuan, maka aturan tersebut juga berpotensi melahirkan penindasan dan kekerasan terhadap perempuan dalam implementasinya.

\section{Kesimpulan dan Saran}

Berdasarkan pada penjelasan dan beberapa hasil penelitian terkait dengan implementasi perlindungan kesehatan reproduksi bagi pekerja perempuan sebagaimana yang tercantum dalam Undang-Undang no. 13 tahun 2003 tentang ketenagakerjaan, maka dapat disimpulkan sebagai berikut.

1. Undang-Undang no. 13 tahun 2003 tentang Ketenagakerjaan telah mengatur beberapa hak kesehatan reproduksi bagi pekerja perempuan, yaitu hak untuk cuti haid pada hari pertama dan kedua, hak untuk tidak bekerja pada malam hari ketika sedang hamil, hak untuk cuti 
melahirkan selama 1,5 bulan sebelum dan 1,5 bulan sesudah melahirkan, hak waktu untuk menyusui, dan hak cuti gugur kandungan selama 1,5 bulan.

2. Rumusan pasal-pasal dalam Undang-Undang no. 13 tahun 2003 tentang Ketenagakerjaan belum menggambarkan hak-hak kesehatan reproduksi perempuan secara menyeluruh. Hal ini terbukti dengan masih adanya masalah kesehatan reproduksi perempuan yang belum diatur dalam Undang-Undang ini. Selain itu, beberapa redaksi dalam rumusan pasal-pasal tersebut justru dapat membuka peluang terjadinya pelanggaran terhadap perlindungan kesehatan reproduksi bagi pekerja perempuan. Hal itu menunjukkan bahwa rumusan yang ada belum sepenuhnya memperhitungkan pengalaman, kebutuhan, dan kepentingan perempuan akan keberadaan reproduksi dan fungsi repoduksi yang dimilikinya yang berbeda dengan laki-laki. Tidak hanya itu, rumusan tentang perlindungan kesehatan reproduksi bagi pekerja perempuan di atas juga belum memperhatikan bagaimana pekerja perempuan dikonstruksi oleh masyarakat. Rumusan tersebut belum memberikan dukungan tentang adanya posisi pekerja perempuan memang tidak mempunyai bargaining power, dan sebaliknya, pengusaha sebagai pemilik modal memegang kekuasaan dan menggunakan uang sebagai kekuatan untuk mengendalikan pekerja perempuan.

3. Pemaparan berbagai kisah hasil penelitian di atas menunjukkan bahwa dalam realitanya, implementasi perlindungan terhadap kesehatan reproduksi bagi pekerja perempuan masih banyak yang tidak berjalan sesuai dengan aturan yang ada dalam Undang-Undang no. 13 tahun 2003 tentang ketenagakerjaan. Dalam realitanya, masih banyak terjadi pelanggaran terhadap hak-hak pekerja perempuan untuk mendapatkan perlindungan terhadap kesehatan reproduksinya

Berkaitan dengan kondisi tersebut, maka penulis menyarankan dan memberikan rekomendasi untuk melakukan revisi terhadap Undang-Undang no. 13 tahun 2003 tentang Ketenagakerjaan dengan memasukkan beberapa hal, yaitu:

1. Memasukkan beberapa hak-hak bagi pekerja perempuan terkait dengan kesehatan reproduksi yang belum diatur, meliputi:

a. Perlindungan terkait dengan kesehatan berencana

b. Perlindungan terkait dengan beberapa masalah terkait Infeksi Saluran Reproduksi yang dapat terjadi akibat kebersihan dan lain sebagainya.

2. Merevisi rumusan dan redaksi yang dapat membuka peluang terjadinya pelanggaran terhadap perlindungan kesehatan reproduksi bagi pekerja perempuan, seperti: 
a. Memasukkan kewajiban bagi pengusaha untuk membantu menjaga atau melindungi kehamilan pekerja perempuan dengan penciptaan suasana dan kondisi kerja yang tidak membahayakan selain aturan larangan kerja pada malam hari.

b. Memasukkan kewajiban pengusaha untuk memudahkan akses pekerja perempuan yang sedang menyusui, melalui penyediaan sarana penitipan anak.

3. Memberlakukan sanksi yang tegas terhadap perusahaan yang melanggar peraturan terkait dengan perlindungan kesehatan reproduksi bagi pekerja perempuan sebagaimana yang sudah diatur dalam Undang-Undang no. 13 tahun 2003 tentang ketenagakerjaan

4. Mewajibkan ekpada pengusaha untuk memberikan pengetahuan dan kesadaran terhadap pekerja perempuan mengenai hak-haknya, khususnya yang terkait dengan kesehatan reproduksinya.

\section{DAFTAR PUSTAKA}

Bacchi, Carol Lee. (1999). Women, policy, and politics: the construction of policy problems. LN: Sage Publications Ltd.

Bhasin, Kamla. (1996). Menggugat patriarki. Yogyakarta: Yayasan Bentang BudayaKalyanamitra.

Fakih, Mansour. (1997). Analisis gender dan transformasi sosial. Yogyakarta: Pustaka Pelajar.

Friedman, Lawrence. (1975). The legal system: a social science perspective. New York: Russel Sage Foundation.

Irianto, Sulistiyowati. (2000). Pendekatan hukum berperspektif perempuan, Dalam Tapi Omas Ihromi. (eds.), Penghapusan diskriminasi terhadap wanita. (h. 92-110). Bandung: PT ALUMNI.

Luhulima, Achie Sudiarti. (2000). Konvensi penghapusan segala bentuk diskriminasi terhadap wanita. Dalam Tapi Omas Ihromi. (eds.), Penghapusan diskriminasi terhadap wanita. (h. 24-62). Bandung: PT ALUMNI.

MacKinnon, Catherine A. (1989). Toward a feminist theory of the state. Massachussets: Harvard University Press.

Maimunah, Margaret Aliyatul. (2008). Kesadaran Perlindungan Kesehatan Reproduksi: Kasus Buruh Perempuan di Kawasan Berikat Nusantara (KBN) Tanjung Priok. Dalam Aris Arif Mundayat (eds.). Bertahan Hidup di Desa atau Tahan Hidup di kota: Balada Buruh Perempuan. (h. 67-103). Jakarta: Women Research Institute.

(2008). Pendidikan dan Kesadaran Hak-Hak Buruh: Kasus Buruh Perempuan di Kawasan Berikat Nusantara (KBN) Cakung. Dalam Aris Arif Mundayat (eds.). 
Bertahan Hidup di Desa atau Tahan Hidup di kota: Balada Buruh Perempuan. (h. 67103). Jakarta: Women Research Institute.

Sadli, Saparinah, dkk. (2006). Implementasi pasal 12 Undang-Undang nOmor 7 Tahun 1984 Pelayanan Kehamilan, Persalinan, dan Pasca Persalinan: Syudi Kasus di Cilincing, Jakarta Utara, Kebumen, dan Jawa Tengah. Jakarta: Kelompok Kerja Convention Watch Universitas Indonesia.

Safa'at, Rachmad. (1998). Buruh Perempuan: Perlindungan Hukum dan Hak Asasi Manusia. Malang: Penerbit IKIP Malang.

Saptari, Ratna dan Holzner, Brigitte. (1997). Perempuan kerja dan perubahan sosial: sebuah pengantar studi perempuan. Jakarta: Kalyanamitra.

Survei Angkatan Kerja Nasional (SAKERNAS). (2006), (2007), (2008). (2010). Jakarta: BPS.

Suzianni, Jenny. (2007). Perlindungan Maternitas Buruh Perempuan di PT. EIA di KBN Marunda Jakarta Utara. Hasil Penelitian tidak diterbitkan.

Tong, Rosemarie Putnam. (1998). Feminist thought: a more comprehensive introduction. Colorado: Westview Press.

Undang-Undang Ketenagakerjaan. 2003. Jakarta: Redaksi Sinar Grafika 